\title{
The End of Voluntarism: Herbert Hoover and the National Credit Corporation
}

James S. Olson

IN THE AUTUMN OF 1931 the United States experienced the most serious economic and financial crisis in its history. The banking system inevitably suffered as factory production, commodity prices, securities prices, and bank deposits all dropped precipitously. Even before the crash the banks had been weakened by ineffective state regulation, mismanagement, decreasing proportions of liquid assets, and overinvestment in speculative securities. Great Britain's decision, on September 21, 1931, to abandon the gold standard further intensified the banking crisis, causing frightened European financiers to unload their American securities and withdraw gold from the country. Bank suspensions had already surpassed all previous records, and national confidence in the banking system was steadily deteriorating. ${ }^{1}$

By September, 1931, complete demoralization pervaded the financial community. Early in the month President Hoover realized the critical need to protect the financial community from public panic and forced liquidation. The nature of his response to the unprecedented crisis was a product of his personal philosophy and successful bureaucratic career.

For Hoover the greatness of the American way of life rested upon its unique synthesis of enlightened individualism

'Annual Report of the Federal Reserve Board (Washington, D.C., 1932), pp. 16-20. Commercial and Financial Chronicle, October 17, 1931; Federal Reserve. Bulletin, XVII (November, 1931), 607; New York Times, January 7, 1932; John K. Galbraith, The Great Crash 1929 (Boston, 1954), pp. 184-85; Paul Trescott, Financing American Enterprise (New York, 1966), p. 199. 
and equality of opportunity. His own successful life, from the agrarian background of West Branch, Iowa, to the distinguished political career in Washington, D.C., reflected American greatness. As a social method, his "American Individualism" guaranteed to every member of the community the right and means to achieve according to his ability. American Individualism also enjoyed the distinction of succeeding in an age of corporate power and interest-group politics. In Hoover's estimate, one of the most extraordinary developments of the Twentieth Century was the growth of voluntary interest groups in America. More important, these power aggregates had arisen almost spontaneously. Such cooperation among these groups represented a blending of self-interest and altruism, and it provided the ideal environment for the flourishing of individual initiative and equality of opportunity. Though motived by self-interest, the leaders of these groups, Hoover firmly believed, were educated, enlightened men capable of working together to insure American social and economic progress. $^{2}$

Government played an important role in Hoover's ideal system. He believed in the decentralization of institutional power because he felt that political and economic groups at the grassroots level were better equipped than distant, centralized establishments to evaluate local conditions and to solve local problems. Yet, the most powerful of those central institutions, the national government, had important obligations to fulfill. Unfortunately, President Hoover has been unjustly maligned by most historians. In actuality, he had long before abandoned laissez-faire strictures upon governmental activism. Already, he had organized the President's Committee on Unemployment Relief to seek means of easing the impact of unemployment, and the Federal Drought Relief Committee to deliver assistance to farmers. Rather than ignore the ups and downs of the business cycle, as previous administrations had done, the government, Hoover believed, must act as the arbiter and coordinator of the interest-group state. By stimulating the creation of cooperatively-controlled voluntary economic institutions, and by regulating their activ-

\footnotetext{
${ }^{2}$ Herbert Hoover, The New Day (Stanford, Calif., 1928), p. 5; Herbert Hoover, American Individualism (New York, 1922), pp. 9, 41-45.
} 
ity through committees of governmental and business officials, the government could guarantee the survival of the noncoercive, individualistic society. ${ }^{3}$

Nevertheless, the President remained keenly aware of the threat government posed to American Individualism. Because of the regulatory responsibilities that accompanied the development of the industrial state, the government had come to represent the single most potent element in American society. In stimulating cooperation and in curbing abuses, the government could only strengthen the nation's beneficient social system. On the other hand, any impulses to expand the authority of the government were dangerous. As an objective, detached arbiter in the economy, the government perpetuated individualism; as an active competitor in the economy, it would destroy the American way of life. ${ }^{4}$

Hoover's successful pre-presidential career had confirmed, in his own mind, the main tenets of this philosophy. While leading the American Relief Administration after the war, he had relied upon voluntary contributions and cooperation among charitable organizations, such as the Red Cross and the Friends Service Committee, to sustain his successful efforts to provide food for an impoverished Europe. As Secretary of Commerce, he had vigorously assisted all attempts to create a political economy dominated by enlightened interest groups. Farm cooperatives, trade associations and councils, labor unions, and professional organizations all exemplified the development of mutual cooperation, and for Hoover the prosperity of the 1920s confirmed their beneficial impact on the economy. ${ }^{5}$ Because of his philosophy and experience, it was quite natural that in responding to the financial crisis of 1931, and the depression in general, Hoover would draw upon his past and attempt to implement a voluntary program of cooperation among bankers to end the cycle of forced liquida-

\footnotetext{
${ }^{3}$ Herbert Hoover, American Individualism, p. 46; William S. Myers, ed., The State Papers and Other Public Writings of Herbort Hoover (New York, 1934), Volume I, p. 382.

${ }^{4}$ Herbert Hoover, American Individualism, pp. 52-54; William S. Myers, State Papers, Volume I, pp. 502-04.

"Herbert Hoover, The Memoirs of Herbert Hoover (New York, 1952), Volume II, pp. 20-23, 63, 169-173.
} 
tion and stimulate the systematic expansion of credit.

On September 8 the President told Eugene Meyer, Governor of the Federal Reserve Board, that cooperative action by the financial community might stabilize the chaotic economic conditions, calm the public, relieve the deflationary pressures on the banks, and eventually initiate an economic expansion. Meyer quickly acquainted each chairman of the twelve Federal Reserve Banks with Hoover's suggestion and asked them all to give it careful consideration. ${ }^{\circ}$ At a meeting of the Federal Reserve Advisory Council on September 15, the President carried his plan a step further by proposing the creation of a voluntary credit pool to which private bankers would subscribe $\$ 500,000,000$ in capital. Meyer was skeptical of the proposal, considering it an inadequate means with which to confront the broad dimensions of the problem. Instead, he urged Hoover to revive the War Finance Corporation and endow it with the massive resources of the federal government. ${ }^{7}$ President Hoover rejected the proposal. He was no doctrinaire ideologue willing to resist expansions of federal authority at all costs, but simply hoped that in the two months before the convening of the Seventy-second Congress an effective private credit organization might be formed to alleviate the crisis and place the country on the road to recovery. The President fully realized that if this proved unsuccessful, the federal government would have to intervene directly to ease the crisis. ${ }^{8}$

${ }^{6}$ Theodore G. Joslin, Hoover Off the Record (New York, 1934), pp. 131-33.

${ }^{7}$ Eugene Meyer, "From Laissez-Faire with William Graham Sumner to the R.F.C." Public Policy, V (1946), 24.

${ }^{8}$ Hoover's attitude toward revival of the War Finance Corporation is a controversial matter, despite the historical consensus which resulted from an article written by Gerald Nash ("Herbert Hoover and the Origins of the Reconstruction Finance Corporation," Mississippi Valley Historical Review, XLVI (December, 1959), 455-468.). Nash concluded that Hoover resisted the revival bitterly until the last moment. Unfortunately, Nash seems to have accepted uncritically Eugene Meyer's claims that it was he, not Hoover, who was responsible for the R.F.C. A survey of the Ogden Mills Papers at the Library of Congress, the George Harrison Papers at Columbia University, and the Herbert Hoover Papers at the Herbert Hoover Presidential Library reveals a different picture. Hoover did prefer the National Credit Corporation to the revival of the War Finance Corporation, but he was by no means a 
Most important in his decision to postpone organization of the War Finance Corporation was Hoover's philosophical revulsion from governmental intervention into the economy. The spector of the War Finance Corporation may have recalled to Hoover's mind the images of a war economy and the all pervasive role assumed by the government during that period. Although he allowed that agencies of governmental control were justifiable when emergency conditions threatened national survival, he felt their extension into the peacetime economy would most certainly spell the downfall of America's unique society. ${ }^{9}$ Rather than risk such a catastrophe, Hoover preferred to grant voluntarism one last chance to prove itself. Only when private resources had been exhausted would he resort to federal planning and control.

After three weeks of pleading and promises, Governor of the Federal Reserve Board Meyer persuaded a group of New York bankers to meet with the President in Washington, D.C. Aware of Hoover's intentions, they privately agreed during the automobile trip from New York not to provide any emergency credit agency. They wanted the federal government to directly channel its resources into the nation's financial establishments. ${ }^{10}$ On October 4 Hoover presented his ideas to them. First, he urged bankers to create immediately a privately-controlled $\$ 500,000,000$ credit pool to rediscount the sound but frozen assets of banks caught in the cycle of forced liquidation. To supplement the activities of the credit association, the President hoped to secure a relaxation of the eligibility requirements of the Federal Reserve System.

vociferous opponent of the W.F.C. Hoping to preclude the calling of a special session of Congress to revive the W.F.C., and hoping that governmental intervention might be avoided, he did opt for the N.C.C., but he also approved immediate drafting of the R.F.C. legislation. The President was quite willing to support a revival of the War Finance Corporation once the National Credit Corporation had been tried. See the New York Times, October 7, 1931; George Harrison to Herbert Hoover, October 7, 1931, Ogden Mills Papers, Library of Congress; Congressional Record, LXXV (July 5, 1932), 14602; Herbert Hoover to George Harrison, October 5, 1931, George Harrison Papers, Columbia University.

${ }^{9}$ Herbert Hoover, American Individualism, pp. 2, 30-31, 47-49.

${ }^{10}$ Eugene Meyer, Unpublished manuscript, Columbia University Oral Research Office, p. 614. 
The President hoped these measures would liquefy the positions of many banks and enable them to cope with the emergency. The bankers, realizing that the financial situation surpassed their own willingness or ability to solve it independently of the federal government, resisted Hoover's proposal. The President then promised that if, in the next two months, the credit association failed to bring stability, he would ask Congress to revive the War Financing Corporation. Only with this assurance of impending governmental intervention did the bankers agree to organize the private credit association."

George Harrison, Governor of the Federal Reserve Bank of New York, quickly organized a committee of leading New York bankers to formulate plans for the credit corporation. The committee began work and quickly received a pledge of $\$ 150,000,000$ from the member banks of the New York Clearing House Association. ${ }^{12}$ On October 13, the committee announced the creation of the National Credit Corporation.

The new Corporation was authorized to issue up to $\$ 1,000,000,000$ in debentures, of which the nation's banks were expected to supply $\$ 500,000,000{ }^{13}$ Any bank could join, provided it subscribed two per cent of its net time and demand deposits to the association. The Corporation's board of directors consisted of the leading banker from each of the twelve Federal Reserve Districts. Structurally, the Corporation was regionally decentralized into local associations in each Federal Reserve District. Each director organized local associations and local loan committees in his district. Upon subscribing to the gold notes of the new Corporation, any bank could apply to its local association for a loan; if approved, the national organization was to disburse the necessary

\footnotetext{
${ }^{11}$ Herbert Hoover to George Harrison, October 5, 1931, George Harrison Papers, Columbia University.

${ }^{12}$ New York Times, October $8,1931$.

${ }_{13}$ "The National Credit Corporation with the New York Trust Company as Agent of the Loan," Debenture Agreement, October 15, 1931, National Archives, Records Group 56, Department of the Treasury, National Credit Corporation; New York Times, October 18, 1931; "Certificate of Incorporation of the National Credit Corporation," October 13, 1931, National Archives, Records Group 56, Department of the Treasury, National Credit Corporation.
} 
funds. ${ }^{14}$

The National Credit Corporation represented the ultimate embodiment of Hoover's personal philosophy. Far from adhering to laissez-faire, the federal government had stimulated private initiatives to achieve recovery. At the same time, the government had restrained itself by not entering the market as a competitor. In calling upon the bankers to organize and operate the credit pool, Hoover expressed his optimistic belief in the efficacy of cooperative action. And the Corporation's organizational framework, vesting the local branches with complete control over the loan-making process, coincided with his belief in the viability of decentralized power structures. For Hoover and his associates the National Credit Association precluded government intervention, and was thus the "American way to assist business . .."15 His ideas, however, were predicated upon the willingness of bankers to commit themselves to full scale cooperation; such unity was not forthcoming.

Hoover's suspicions about the depth of the Bankers' commitment to the Corporation were quickly aroused following its formal organization. Although pleased with its prompt establishment, the President was dissatisfied with the delays in the actual disbursement of funds. During the last week of October and the first week of November Hoover and his Undersecretary of the Treasury Ogden Mills began sending telegrams to the national and local leaders of the Corporation, criticizing them for their procrastination. ${ }^{16}$ The officials of the Corporation apologized for the delays and claimed that organization of the local associations was consuming more

14"Plan of Organization of the National Credit Corporation," Unpublished manuscript, October 14, 1931 and "National Credit Corporation Board of Directors," Unpublished manuscript, National Archives, Records Group 56, Department of the Treasury, National Credit Corporation.

${ }^{15}$ New York Times, October 7, 1931.

${ }^{16}$ Herbert Hoover to George H. Reynolds, November 6, 1931, Herbert Hoover Presidential Library, Presidential Papers, Financial, National Credit Corporation. Folder $G$ in this collection of the Hoover Papers includes many telegrams from Hoover and Mills to Individual bankers urging them to move forward with the National Credit Corporation program. 
time than had been anticipated. ${ }^{17}$ Finally, on November 7 the directors announced that the National Credit Corporation had formally opened its doors for business, although final organization still had not been completed in all of the Federal Reserve Districts. ${ }^{18}$

Despite his displeasure with the early operations of the National Credit Corporation, President Hoover was satisfied with the impact his proposal apparently had on the economy. Bank failures in October dropped weekly after the announcement of the plan, and suspensions for the first half of November were among the lowest of the year. ${ }^{10}$ Late in October, 1931 the prices of common and preferred stocks and of corporate bonds rallied. ${ }^{20}$ At this stage Hoover had every reason to believe that the National Credit Corporation was going to be a success, and that a revival of the War Finance Corporation would prove to be unnecessary.

Unfortunately, the economic upturn resulted in even further delays in the operation of the National Credit Corporation. Hoping that the financial recovery would relieve the pressure on the Corporation to make some immediate loans, the officers decided in the first week of November to suspend their first call for a ten per cent installment on all of the commitments made by member banks. Consequently, the Corporation's officers relaxed for several weeks and postponed making loans, cautiously hoping that the National Credit Corporation could be dissolved without undertaking extensive loan commitments. ${ }^{21}$ By December, they still had made less than $\$ 10,000,000$ in loans. ${ }^{22}$

${ }^{17}$ Mortimer Buckner to Ogden Mills, October 26, 1931, Nátional Archives, Records Group 56, Department of the Treasury, National Credit Corporation; Ogden Mills to Walter Frew, October 30, 1931, Ogden Mills Papers, Library of Congress.

${ }^{18}$ New York Times, November $7,1931$.

${ }^{19}$ New York Times, November 9 and December 19, 1931.

${ }^{20}$ Federal Reserve Bulletin, XVII (December, 1931), 665.

${ }^{21}$ Mortimer Buckner to Theodore Joslin, November 17, 1931, Herbert Hoover Presidential Library, Presidential Papers, Financial, National Credit Corporation; George M. Reynolds to Herbert Hoover, November 4, 1931, Herbert Hoover Presidential Library, Presidential Papers, Financial, National Credit Corporation.

${ }^{22}$ U.S. Congress, Senate, Committee on Banking and Currency, Hearings on S. 1, Creation of a Reconstruction Finance Corporation, 72nd Cong., lst Sess., 1932, p. 68. 
Their hopes, however, were quickly shattered. Whether the October rally represented a seasonal fluctuation, a minor adjustment after the serious declines which had ensued since England left the gold standard, or the response to a temporary rejuvenation of public confidence by announcement of the credit pool, it was shortlived, collapsing late in November. Bank failures again reached alarming numbers, and stock and bond prices entered another period of decline. ${ }^{23}$ The National Credit Corporation had failed.

President Hoover, however, was not responsible for the failure. The cautiousness of the bankers inhibited the actual operations of the Corporation. As originally proposed, the National Credit Corporation was part of a financial program which also embraced the broadening of the Federal Reserve eligibility requirements. Under these provisions, bankers hoped that the frozen collateral the Corporation acquired from its loans might be rediscounted by the Federal Reserve Banks. But when the measure to reform the Federal Reserve met stiff resistance from Congressional Democrats in November, 1931, it became evident that such rediscounting policies might not be forthcoming. ${ }^{24}$ By loaning their pooled assets to threatened banks, then, the solvent members of the Corporation would indirectly be accepting slow and frozen assets into their portfolios, a development which the bankers studiously avoided. In view of the cautiousness of the financial community, President Hoover called for the establishment of a Reconstruction Finance Corporation.

In proposing the Reconstruction Finance Corporation Hoover had suspended his personal creed. The National Credit Corporation represented the last attempt by the Republican President to solve the depression by voluntary action in the private sector. The National Credit Corporation had been an utter failure as a total solution to the depression. That failure, however, marked a watershed in the history of the federal government, for when Hoover abandoned the

${ }^{23}$ Federal Reserve Bulletin, XVII (December, 1931), 665; New York Times, December 19, 1931 and January 1, 7, and 11, 1932.

${ }^{24}$ S. E. Harris, "Banking and Currency Legislation," Quarterly Journal of Economics, XLVI (May, 1932), 547-48; U. S. Congress, Hearings on S. 1., pp. 176-77. 
National Credit Corporation he also abandoned realistic hopes for an active but limited federal government. Contrary to historical consensus, Herbert Hoover was a sensitive man willing to undertake whatever measures he believed necessary to bring recovery. Herbert Hoover, once the nation's most articulate spokesman for voluntarism and a circumscribed federal government, had directed America, with the termination of the National Credit Corporation and the creation of the Reconstruction Finance Corporation, toward an embryonic governmental-business relationship which would quickly evolve into the New Deal.

Although the proposal appears mild when compared with the vast changes which have occurred since 1932 in the responsibilities of the federal government, Hoover had actually taken an extraordinary step forward in the history of American public policy. Indeed, the tragedy of Hoover's reputation lies in the comparison historians have made between the Republican president and those presidents who followed him. Hoover becomes a landmark figure in the history of American politics when one compares him with his predecessors. In 1931, for the first time, an American President had admitted that the federal government was responsible for maintaining the economic welfare of the nation, for controlling the operation of the business cycle. For Hoover the processes of natural liquidation and deflation were too severe and too productive of suffering and social injustice to make laissez-faire policies tenable. The depression was so serious, and its impact so widespread, that it constituted an unprecedented national emergency; the privately-owned financial, commercial and industrial sectors of the economy were powerless to stop the decline. They simply did not possess the vision or the economic resources necessary to take effective action. At that point President Hoover made a momentous break with the past. With his proposal, on December 7, 1931, for the creation of a Reconstruction Finance Corporation, President Hoover initiated a movement leading directly to the New Deal. In reality, the New Deal began not in the spring of 1933 but in the winter of 1931-32 when Herbert Hoover transcended voluntarism and brought on a direct intervention of the federal government into the economy. 
Copyright of Annals of Iowa is the property of State of Iowa, by \& through the State Historical Society of Iowa and its content may not be copied or emailed to multiple sites or posted to a listserv without the copyright holder's express written permission. However, users may print, download, or email articles for individual use. 